\title{
Preparation of chitosan and its application on ginger paste and fruit juice as food preservative
}

\author{
Mohammad Tanvir Sarwar ${ }^{1}$, Md. Sidur Rahman ${ }^{1}$, Md. Zakir Hossain ${ }^{2}$, M. Mashiul Alam ${ }^{1}$ \\ ${ }^{1}$ Department of Applied Nutrition and Food Technology, Islamic University, Kushtia-7003, Bangladesh \\ ${ }^{2}$ BioMedNanoTech Inc., Suit 319, 500S University Avenue, Littlerock, Arkansas, USA
}

Email address:

tanvirsarwariu@gmail.com (T. Sarwar)

To cite this article:

Mohammad Tanvir Sarwar, Md. Sidur Rahman, Md. Zakir Hossain, M. Mashiul Alam. Preparation of Chitosan and Its Application on Ginger Paste and Fruit Juice as Food Preservative. Journal of Food and Nutrition Sciences. Vol. 2, No. 6, 2014, pp. $243-249$.

doi: $10.11648 /$ j.jfns.20140206.11

\begin{abstract}
Chitosan is a nitrogen containing polysaccharides that forms a semitransparent horny substance and is a principal constituent of the exoskeleton or outer covering of insects, crustaceans and arachnids. In recent years application of natural antimicrobials instead of conventional ones, due to their hazardous effects on health, has got serious attentions. On the basis of the results of different studies, chitosan, a natural bio-degradable and non-toxic biopolysaccharide derived from chitin, has potential to be used as a natural antimicrobial. Chitosan has exhibited high antimicrobial activity against a wide variety of pathogenic and spoilage microorganisms, including fungi, and Gram-positive and Gram-negative bacteria. In the present study the author prepared chitosan sample and used it as food preservative. Chitosan was prepared in two processes. Where one sample was prepared applying high temperature and pressure and other was without the application of high temperature and pressure. Chitosan applied as food preservative in orange juice and ginger paste. Microbial count was taken at 3, 8 and 16 days by MPN (Minimal Probable Number) method. Sub culture in selective media was done to distinguish coliform presence. The study work found that preservative used as chitosan sample-2 was found comparatively acceptable. By the study the shelf life of ginger and juice was observed for organoleptic properties which were acceptable. The experiment was done in room temperature. The ginger paste was found to be acceptable on day 8 as bacterial count was found $1.4 \times 10^{6}$ and fungal count $7.5 \times 10^{5}$. The orange juice was found to be acceptable on day 8 as bacterial count was found $5.5 \times 10^{4}$. Where at same day fungal count $2.6 \times 10^{5}$. Further investigation of health affect of chitosan preserved food is required in future. Chitosan has a great impact to eliminate chemical preservative as it works efficiently as preservative.
\end{abstract}

Keywords: Chitosan, Preservative, Coliform, Antimicrobial

\section{Introduction}

Chitosan and its derivatives are examples of value-added materials. They are produced from chitin, which is a natural carbohydrate polymer found in the skeleton of crustaceans, such as crab, shrimp and lobster, as well as in the exoskeleton of marine zooplankton spp., including coral and jellyfishes ${ }^{[1]}$. Insects, such as butterflies and ladybugs, also have chitin in their wings and the cell walls of yeast, mushrooms and other fungi also contain this substance ${ }^{[2]}$. Chitin, after cellulose, is the most abundant polysaccharide in nature, and is primarily present in the exoskeletons of crustaceans (such as crab, shrimp, lobster etc.) and also in various insects, worms, fungi and mushrooms in varying amount. In addition, recent advances in fermentation technology suggest that the cultivation of fungi can provide an alternative source of chitosan. Chitin makes up to $45 \%$ of the cell wall of Aspergillus niger and Mucor rouxii and 20\% of the cell wall of Penicillium notatum ${ }^{[3]}$. Chitosan is a linear polysaccharide consisting of $\beta$-( $1 \rightarrow 4)$-linked 2-amino-2- deoxy-D-glucose residues, originating from deacetylated derivative of chitin, which is the second most abundant polysaccharide in nature after cellulose. It was non-toxic, biodegradable, biofunctional, and biocompatible. Chitosan has strong antimicrobial and antifungal activities that could effectively control fruit decay $^{[4]}$. Today, preference of consumers for foods without chemical preservatives has led to the discovery of new natural antimicrobial agents. The antimicrobial and antifungal activities of chitosan and its degradation products such as, chitooligomers and low molecular weight chitosans have been 
studied by several researchers, with particular emphasis on their ability as a food preservative ${ }^{[5]}$. Considering the superior properties of chitosan, it has been successfully used in many postharvest fruits and vegetables, such as grape, berry, jujube and fresh-cut lotus $\operatorname{root}^{[6]-[9]}$. Deacetylation step often performed using concentrated alkaline solution at elevated temperature for defined periods. Two the most important physicochemical characteristics of chitosan are its degree of deacetylation (DDA) and the molecular weight. The DDA has influence on all the physicochemical properties such as molecular weight, viscosity, solubility, etc. This parameter can also influence the solubility of the polymer in organic or aqueous solvents. By increasing the DDA, the solubility increases. Molecular weight affects antibacterial properties $^{[10]-[11]}$. In the recent decades, extensive investigations have been carried out to prepare functional chitosan and to increase its solubility in water in order to broaden its application. One way is modification of production process of chitosan. Qin et al. (2006) found that optimum chitosan as food preservative should be water-insoluble chitosan from mild depolymerization of native chitosan. Another way is modification of chitosan with derivation which explain more below. Researchs on the possibility of developing chitosan as a natural antimicrobial have increased especially in two decades. Chitosan can be applied to extend the storage life of different categories of food materials. Martín-Diana et al. (2009) incorporated chitosan in unpasteurized orange juice and evaluated of quality and nutritional markers. Their results recommend the use of chitosan at concentrations up to $1 \mathrm{~g} \mathrm{~L}-1$ to extend quality and preserve ascorbic acid and carotenoids during storage time of fresh orange juice, thus avoiding the use of standard thermal treatments which produces a negative impact on the nutritional value. Coma et al. (2003) suggested the application of chitosan as preservative in dairy products. number of researchers have focused on the antibacterial action modes of chitosan and its derivatives. The two major suggested mechanisms are: (1) The binding of cationic chitosan to sialic acid in phospholipids, and consequently restraining the movement of microbiological substances, and (2) penetration of oligomeric chitosan into the cells of microorganisms and prevention the growth of cells by preventing the transformation of DNA into $\mathrm{RNA}^{[12]}$.

Chung et al. (2004) demonstrated the relationship between the antibacterial activity of chitosan and the surface characteristics of the cell wall of Gram-positive and Gram-negative bacteria. They saw that more adsorbed chitosan, due to more negatively charged cell surfaces, would result in greater changes in the structure of the cell wall and in the permeability of the cell membrane. As a result, Gram-negative bacteria due to their

more negatively charged cell surfaces are more susceptible to chitosan, and sensitivity of the Gram-positive bacteria was highly variable. Latter, Raafa et al. (2008) demonstrated that the mode of action of chitosan is probably more complex than simple interaction of chitosan with cell membrane, and it involves a number of events, which may ultimately lead to a killing process. Analysis of transcriptional response data in their study revealed that chitosan treatment leads to multiple changes in the expression profiles of Staphylococcus aureus SG511 genes involved in the regulation of stress and autolysis, as well as gene associated with energy metabolism. Important parameters affecting antimicrobial activity of chitosan are the molecular weight (MW) and concentration of chitosan, and type of the microorganism. Jeon and kim (2000) reported the MW of chitooligosaccharides is critical for microorganism inhibition and required to be higher than $10 \mathrm{kDa}$. No et al. (2002) found chitosan has higher antimicrobial activity than chitosan oligomers at a $0.1 \%$ concentration. In a study, Liu et al. (2006) evaluated the antibacterial properties of chitosans with different MW (55 to $155 \mathrm{kDa}$ ) but with same degree of deacetylation $(80 \% \pm 0.29)$, against $E$. coli with different concentrations. According to their result, all chitosans had antibacterial activity at concentrations over $200 \mathrm{ppm}$, thought the antibacterial activity of low MW chitosan was higher than that of the high MW samples. Omura et al. (2002) measured the antimicrobial activity of chitosan and chito-oligosaccharides with different MW without acetylated groups. They observed high MW chitosans showed strong antimicrobial activity against Gram-positive bacteria, whereas chitosans of $11 \mathrm{kDa}$ and 20-30 kDa molecular weights were most effective against Gram-negative bacteria. Zheng and Zhu (2003) reported that the effect of chitosan with MW below 300 $\mathrm{kDa}$ on Staphylococcus aureus was strengthened as the MW increased, whereas the antimicrobial effect on E. coli increased as the MW was decreased. Chitosan are used in dietary supplements, water treatment, food preservation, agriculture, cosmetics, pulp \& paper and medicinal application ${ }^{[13]}$. There has been a large increase in chitosan research during the past decade. This is due to its biocompatibility, biodegradability, non-toxicity, and other unique properties such as film forming ability, chelation and adsorption properties and antimicrobial activity ${ }^{[14]}$.

\section{Methodology}

The preservative use of chitosan can be done by various ways and many factors affect here. The factors ware Production method, Culture media incubation temperature. Two types of chitosan sample produced were used in orange juice and ginger paste. The preservative use of chitosan in above food items ware main research work, colony culture, sub culture and specific microorganisms (Coliform) distinguished ware also in this thesis work.

Preparation of chitosan from shrimp shell:

Procedure: For sample-1

For the Preparation of chitosan powder for sample-1, Shrimp Shell dry \& weight 100 gm taken. Then the following step done carefully.

\section{Step- 1 :Deprotenization:}

Taken 100 gm of shrimp shell was washed \& dried in sun for 6 days . In the sundry they are grinding. It was prepared for producing chitosan powder. It was a procedure where protein molecules of shell may be separated. For this process chemical 
used 4\% Sodium hydroxide $(\mathrm{NaOH})$. Taken $1000 \mathrm{ml} 4 \%$ Sodium hydroxide $(\mathrm{NaOH})$ solution in a beaker. The ratio of solid shrimp and solution may be $1: 10$. It's placed under the oven for 2 hours in temperature $65^{\circ} \mathrm{C}$. solid:solvent;(1: $10, \mathrm{w} / \mathrm{v})$.

Step- 2 : Demineralization:

Taken the beaker from oven \& cool. Then it was washed with distill water. The washing the shrimp shell than taken into beaker \& $1 \mathrm{~N} \mathrm{HC1}$ for 30min. at room, solid:solvent $(1: 15, \mathrm{w} / \mathrm{v})$ react with shell. The mineral that present ware releasing from shell.

\section{Step- 3: Decoloration :}

Shrimp shell than washed with distill water carefully. Shrimp shell taken into a beaker \& extract with Acetone \& Bleaching with $0.5 \%$ Sodium Hypochlorite $(\mathrm{NaOCl} w / \mathrm{v})$ for 5 min. at room temperature. Here shrimp shell \& Acetone, Sodium Hypochlorite ratio that mean solid : solvent ratio 1:10 $(\mathrm{w} / \mathrm{v})$.

\section{Step- 4: Deacetylation :}

The Shrimp shell washed with distilled water \& drying. Shrimp shell taken into beaker \& 50\% Sodium Hydroxide $(\mathrm{NaOH})$ react shell 30 min.at 115 Psi \& $121^{\circ} \mathrm{C}$ temperature. Solid \& Solvent ratio 1:10 (w/v). Then it washed with distill water.

Sample-1 preparation of 42 gm of Chitosan powder from 100 gm of Shrimp Shell.

Procedure: For sample - 2 (modified process)

For the Preparation of chitosan powder for sample-2 Shrimp Shell dry \& weight, 100 gm taken. Then the following step done carefully.

\section{Step- 1: Deprotenization:}

Taken 100 gm of shrimp shell that was already washed \& drying. In the sundry they ware grinding. It was prepared for producing chitosan. It was a procedure where protein molecules of shell may be separated. For this process chemical use $4 \%$ Sodium hydroxide $(\mathrm{NaOH})$. Taken $1000 \mathrm{ml} 4 \%$ Sodium hydroxide $(\mathrm{NaOH})$ solution in a beaker. The ratio of solid shrimp and solution may be $1: 10$. It's place under the oven for 2 hours in temperature $65^{\circ} \mathrm{C}$.

Step- 2 Demineralization:

Taken the beaker from oven $\&$ cool. Then it was washed with distill water. The washing the shrimp shell than taken into beaker \& $1 \mathrm{~N} \mathrm{HC} 1$ for $30 \mathrm{~min}$ at room tern. solid:solvent (1:10 $\mathrm{w} / \mathrm{v}$ ) react with shell. The mineral that present are release from shell. Shrimp shell than washed with distill water carefully.

Sample-2 Produce 48 gms of Chitosan powder form 100 gms of Shrimp Shell

Preparation of orange juice before applying chitosan:

Peel the orange carefully so that pulp was not broken. Then pulp was taken into blender and blending well. Add sugar .500 $\mathrm{ml}$ of orange juice are produce. For sample-1: $100 \mathrm{ml}$ of orange juice was taken into beaker and add .25 gm of chitosan. Then keep it normal condition. For sample- 2: $100 \mathrm{ml}$ of orange juice was taken into beaker and add $500 \mathrm{mg}$ of chitosan. Then keep it normal condition. For normal sample: $100 \mathrm{ml}$ of orange juice was take into beaker and no chitosan add. Put all the samples in polyethene \& sealing well by sealing machine.
Then keep it normal condition.

Organoleptic Test:
1. Color
Normal
2. Shape
Normal
3. Size
Normal
4. Test
Normal
5. Flavor
Normal

First Microbial Test of Juice (Bacterial Test): After 3 days for bacterial test first media was prepared. For the $250 \mathrm{ml}$ of bacterial media 1. Nutrient taken $7 \mathrm{gm} \mathrm{2.} \mathrm{Agar} \mathrm{taken} 1 \mathrm{gm}$. Those were dissolve with $250 \mathrm{ml}$ of distill water. Those media were sterilized by automatic sterilizer at $121^{\circ} \mathrm{c} \& 20 \mathrm{~min}$. Instrument sterilization: Test tube, Petri dish, Stirrer, Tips washed well. Every test tube taken $9 \mathrm{ml}$ distills water \& packed with cotton. Media, Petri dish, Test tube, Stirrer were sterilized by automatic sterilizer $121^{\circ}$ c \& $20 \mathrm{~min}$. Test for sample - 1,2 \& normal sample ; 3 times dilution : Juice simple$1,2 \&$ normal sample taken $1 \mathrm{ml}$ by micropipette \& put into 9 $\mathrm{ml}$ of test-tube water respectively. Then from 1 st test-tube taken $1 \mathrm{ml} \&$ put into 2 nd test-tube. It makes $10 \mathrm{ml}$. Then from 2nd test-tube taken $1 \mathrm{ml} \&$ put into 3 rd test-tube. It made 10 $\mathrm{ml}$. From the conical flask media was taken into Petridis in optimum amount. Then from 3rd dilution test-tube taken small amount of sample steering upon the petri dish. From the $3^{\text {rd }}$ test tube each sample taken 200 micro-liter \& put upon petri dish. Above those work were done in laminer flow hood those Petridis are put into incubator at $38^{\circ} \mathrm{C}$ for 24 hours.

First Microbial Test of Juice (Fungal Test): After 3 Days for fungal test first media was prepared. For the $250 \mathrm{ml}$ of fungal media $10 \mathrm{gm}$ potato dextrose agar taken. Those were dissolve with $250 \mathrm{ml}$ of distill water. Those media were sterilized by automatic sterilizer at $121^{\circ} \mathrm{c} \& 20 \mathrm{~min}$. Instrument sterilization: Test tube, Petri dish, Stirer, Tips washed well. Every test tube taken $9 \mathrm{ml}$ distills water \& packed with cotton. Media, Petridis, Test tube, stirrer were sterilized by automatic sterilizer $121^{\circ} \mathrm{c} \& 20 \mathrm{~min}$. Test for sample - 1,2 \& normal sample ; 3 times dilution: Juice sample- 1, 2 \& normal sample taken $1 \mathrm{ml}$ by micropipette $\&$ put into $9 \mathrm{ml}$ of test-tube water respectively. Then from 1 st test-tube take $1 \mathrm{ml} \&$ put into 2 nd test-tube. It makes $10 \mathrm{ml}$. Then from 2 nd test-tube take $1 \mathrm{ml} \&$ put into 3 rd test-tube. It make $10 \mathrm{ml}$. From the conical flask media is take into petri dish in optimum amount. Then from 3rd dilution test-tube take small amount of sample steering upon the petri dish from the $3^{\text {rd }}$ test tube each sample taken 200 micro-liter \& put upon petri dish. Above those works are done in laminer flow hood those petri dish were put into incubator at $38^{\circ} \mathrm{C}$ for 24 hours.

Second Microbial Test of Juice (Bacterial Test): After 8 days for bacterial test first media was prepared. For the $250 \mathrm{ml}$ of bacterial media 1. Nutrient taken $7 \mathrm{gm} \mathrm{2.} \mathrm{Agar} \mathrm{taken} 1 \mathrm{gm}$. Those were dissolved with $250 \mathrm{ml}$ of distill water. Those media were sterilized by automatic sterilizer at $121^{\circ}$ c \& 20 min. Instrument sterilization: Test tube, Petridish, Stirer, and Tips washed well. Every test tube taken $9 \mathrm{ml}$ distills water \& packed with cotton. Media, Petri dish, Test tube, Stirrer were sterilized by automatic sterilizer $121^{\circ}$ c \& $20 \mathrm{~min}$. Test for 
sample - 1,2 \& normal sample ; 4 times dilution : Juice sample- $1,2 \&$ normal sample taken $1 \mathrm{ml}$ by micropipette $\&$ put into Mel of test-tube water respectively. Then from $1 \mathrm{st}$ test-tube taken $1 \mathrm{ml} \&$ put into 2 nd test-tube. It made $10 \mathrm{ml}$. Then from 2 nd test-tube taken $1 \mathrm{ml} \&$ put into 3 rd test-tube. It made $10 \mathrm{ml}$. From the conical flask media was taken into Petridis in optimum amount. Then from 3rd dilution test-tube taken small amount of sample steering upon the petri dish. From the $3^{\text {rd }}$ test tube each sample taken 200 micro-liter $\&$ put upon Petridis. Above that work were done in laminer flow hood that petri dish are put into incubator at $38^{\circ} \mathrm{C}$ for 24 hours.

Second Microbial Test of Juice (Fungal Test): After 8 days for fungal test first media was prepared. For the $250 \mathrm{ml}$ of fungal media $10 \mathrm{gm}$ potato dextrose agar taken. Those were dissolved with $250 \mathrm{ml}$ of distill water. Those media were sterilized by automatic sterilizer at $121^{\circ} \mathrm{C} \& 20 \mathrm{~min}$. Instrument sterilization: Test tube, petri dish, stirrer micropipette tips washed well. Every test tube taken $9 \mathrm{ml}$ distills water \& packed with cotton. Media, petri dish, Test tube, stirrer, sterilized by automatic sterilizer $121^{\circ} \mathrm{c} \& 20 \mathrm{~min}$. Test for sample - 1,2 \& normal sample ; 3 times dilution : Juice sample- 1, $2 \&$ normal sample taken $1 \mathrm{ml}$ by micropipette $\&$ put into $9 \mathrm{ml}$ of test-tube water respectively. Then from $1 \mathrm{st}$ test-tube taken $1 \mathrm{ml} \&$ put into 2 nd test-tube makes $10 \mathrm{ml}$. Then from 2 nd test-tube taken $1 \mathrm{ml} \&$ put into 3 rd test-tube. It made $10 \mathrm{ml}$. From the conical flask media was take into Petri dish in optimum amount. Then from 3rd dilution test-tube taken small amount of sample steering upon the petri dish from the $3^{\text {rd }}$ test tube each sample taken 200 micro-liter \& put on petri dish. Above those work were done in laminerflow those petri dish were put into incubator at $38^{\circ} \mathrm{C}$ for 24 hours.

Third Microbial Test of Juice (Bacterial Test): After 16 days for bacterial test first media was prepared. For the $250 \mathrm{ml}$ of bacterial media 1.Nutrient taken $7 \mathrm{gm} \mathrm{2}$. Agar taken $1 \mathrm{gm}$. Those were dissolved with $250 \mathrm{ml}$ of distill water. Those media were sterilized by automatic sterilizer at $121^{\circ}$ c \& 20 min. Instrument sterilization: Test tube. Every test tube taken $9 \mathrm{ml}$ distills water \& packed with cotton. Media, Petridis, Test tube, Stirrer were sterilized by automatic sterilizer $121^{\circ}$ c \& 20 min. Test for sample - 1,2 \& normal sample ; 4 times dilution : Juice sample- 1, 2 \& normal sample taken $1 \mathrm{ml}$ by micropipette \& put into $9 \mathrm{ml}$ of test-tube water respectively. Then from 1 st test-tube taken $1 \mathrm{ml} \&$ put into 2 nd test-tube. It made $10 \mathrm{ml}$. Then from 2 nd test-tube taken $1 \mathrm{ml} \&$ put into $3 \mathrm{rd}$ test-tube. It made $10 \mathrm{ml}$. From the conical flask media was taken into Petridis in optimum amount. Then from 3rd dilution test-tube taken small amount of sample steering upon the petridis. From the $3^{\text {rd }}$ test tube each sample taken 200 micro-liter \& put upon petri dish. Above those work were done in laminerflow those Petridis were put into incubator at $38^{\circ} \mathrm{C}$ for 24 hours.

Third Microbial Test of Juice (Fungal Test): After 16 days for fungal test first media was prepared. For the $250 \mathrm{ml}$ of fungal media $10 \mathrm{gm}$ potato dextrose agar taken. Those were dissolved with $250 \mathrm{ml}$ of distill water. Those media were sterilized by

Automatic sterilization was performed at $121^{\circ} \mathrm{C} \& 20 \mathrm{~min}$.
Every test tube taken $9 \mathrm{ml}$ distills water $\&$ packed with cotton. Test for sample - 1, 2 \& normal sample ; 3 times dilution : Juice sample- 1, 2 \& normal sample taken $1 \mathrm{ml}$ by micropipette \& put into $9 \mathrm{ml}$ of test-tube water respectively. Then from 1 st test-tube take $1 \mathrm{ml} \&$ put into 2 nd test-tube. It make $10 \mathrm{ml}$. Then from 2 nd test-tube taken $1 \mathrm{ml} \&$ put into $3 \mathrm{rd}$ test-tube. It made $10 \mathrm{ml}$. From the conical flask media was take into Petridis in optimum amount. Then from 3rd dilution test-tube take small amount of sample steering upon the Petri dish. From the $3^{\text {rd }}$ test tube each sample taken 200 micro-liter $\&$ put upon petri dish. Above those work done in laminerflow those Petridis were put into incubator at $38^{\circ} \mathrm{C}$ for 24 hours.

Preparation of Ginger Paste used of Chitosan Powder:

Production Procedure: Ginger collect and it washed into water clearly than it weight. For sample-1. 50 gm of Ginger in to blender and blending well $0.5 \mathrm{gm}$ of chitosan powder mixed well with ginger paste. It was then taken into polythene. Chitosan powder mixed with ginger paste $(0.5 \%)$ sealing \& keeped it in normal condition. For sample-2, 50 gm of Ginger into a blender and blending well. One gm of chitosan powder mixed well with ginger paste. It was then taken into Polythene. Chitosan powder mixed with ginger paste ( $1 \%$ ) sealing \& keep it in normal condition. For normal Ginger sample: $50 \mathrm{gm}$ of Ginger into a blender and blending well. No chitosan powder mixed in ginger paste. Ginger paste is produced keep it into normal condition.

Organoleptic Test:
1. Color
Normal
2. Shape
Normal
3. Size
Normal
4. Test
Normal

First Microbial Test of Ginger (Bacterial test): After 3 days for bacterial count was done. Test for sample $-1,2 \&$ normal sample; 3 times dilution : ginger sample- 1, 2 \& normal sample taken $1 \mathrm{ml}$ by micropipette \& put into $9 \mathrm{ml}$ of test-tube water respectively. Then from 1 st test-tube take $1 \mathrm{ml} \&$ put into 2 nd test-tube. It made $10 \mathrm{ml}$. Then from 2 nd test-tube take $1 \mathrm{ml} \&$ put into $3 \mathrm{rd}$ test-tube. It made $10 \mathrm{ml}$. From the conical flask media was taken into Petridis in optimum amount. Then from 3rd dilution test-tube taken small amount of sample steering upon the petri dish from the $3^{\text {rd }}$ test tube each sample taken 200 micro-liter \& put upon Petridis. Above those work done in laminerflow those Petridis put into incubator at $38^{\circ} \mathrm{C}$ for 24 hours.

First Microbial Test of ginger (Fungal Test): After 3 Days for fungal test first media was prepared. For the $250 \mathrm{ml}$ of fungal media low gm potato dextrose agar taken. Those were dissolved with $250 \mathrm{ml}$ of distill water. Those media were sterilized by automatic sterilizer at $121^{\circ} \mathrm{C} \& 20 \mathrm{~min}$. Every test tube taken $9 \mathrm{ml}$ distills water \& packed with cotton. Test of sample - 1, 2 \& normal sample; 3 times dilution: ginger sample- $1,2 \&$ normal sample taken $1 \mathrm{ml}$ by micropipette $\&$ put into $9 \mathrm{ml}$ of test-tube water respectively. Then from $1 \mathrm{st}$ test-tube take $1 \mathrm{ml} \&$ put into 2 nd test-tube. It made $10 \mathrm{ml}$. Then from 2 nd test-tube taken $1 \mathrm{ml} \&$ put into 3 rd test-tube. It made $10 \mathrm{ml}$. From the conical flask media was taken into 
Petridis in optimum amount. Then from 3rd dilution test-tube take small amount of sample steering upon the Petridis. From the $3^{\text {rd }}$ test tube each sample taken 200 micro-liter $\&$ put upon Petridis. Petri dish were incubated at $38^{\circ} \mathrm{C}$ for 24 hours.

Second Microbial Test of Ginger (Bacterial test ): After 8 days for bacterial test first media was prepared. For the $250 \mathrm{ml}$ of bacterial media Nutrient taken $7 \mathrm{gm} \&$ Agar taken $1 \mathrm{gm}$. Those were dissolved with $250 \mathrm{ml}$ of distill water. Those media were sterilized by automatic sterilizer at $121^{\circ}$ c \& 20 min. Test for sample - 1,2 \& normal sample ; 4 times dilution : ginger sample- 1, $2 \&$ normal sample taken $1 \mathrm{ml}$ by micropipette \& put into $9 \mathrm{ml}$ of test-tube water respectively. Then from 1 st test-tube taken $1 \mathrm{ml} \&$ put into 2 nd test-tube. It made $10 \mathrm{ml}$. Then from $2 \mathrm{nd}$ test-tube taken $1 \mathrm{ml} \&$ put into $3 \mathrm{rd}$ test-tube. It made $10 \mathrm{ml}$. From the conical flask media was taken into Petridis in optimum amount. Then from 3rd dilution test-tube take small amount of sample steering upon the Petri dish. From the $3^{\text {rd }}$ test tube each sample taken 200 micro-liter $\&$ put upon Petridis. Above those work done in laminerflow and incubated at $38^{\circ} \mathrm{C}$ for 24 hours.

Second Microbial Test of ginger (Fungal Test): After 8 Days for fungal test first media was prepared. For the $250 \mathrm{ml}$ of fungal media $10 \mathrm{gm}$ potato dextrose agar taken. Those were dissolved with $250 \mathrm{ml}$ of distill water. Test for sample - 1, 2 \& normal sample; 4 times dilution: ginger sample- 1, 2 \& normal sample taken $1 \mathrm{ml}$ by micropipette \& put into $9 \mathrm{ml}$ of test-tube water respectively. Then from 1 st test-tube take $1 \mathrm{ml} \&$ put into 2 nd test-tube. It made $10 \mathrm{ml}$. Then from 2 nd test-tube made $1 \mathrm{ml} \&$ put into $3 \mathrm{rd}$ test-tube. It made $10 \mathrm{ml}$. From the conical flask media was taken into petri dish in optimum amount. Then from 3rd dilution test-tube taken small amount of sample steering upon the petridis. From the $3^{\text {rd }}$ test tube each sample taken 200 micro-liter \& put upon Petridis. Above those work done in laminerflow those Petridis put into incubator at $38^{\circ} \mathrm{C}$ for 24 hours.

Third Microbial Test of Ginger (Bacterial test): After 16 days for bacterial test first media was prepared. For the $250 \mathrm{ml}$ of bacterial media Nutrient taken $7 \mathrm{gm} \&$ Agar taken $1 \mathrm{gm}$. Those were dissolved with $250 \mathrm{ml}$ of distill water. Those media were sterilized by automatic sterilizer at $121^{\circ}$ c \& 20 min. Instrument sterilization: Every test tube taken $9 \mathrm{ml}$ distills water $\&$ packed with cotton. Media, Petridis, Test tube, Stirrer were sterilized by automatic sterilizer $121^{\circ} \mathrm{c} \& 20 \mathrm{~min}$. Test for sample - 1,2 \& normal sample ; 5 times dilution : ginger sumple- 1, 2 \& normal sample taken $1 \mathrm{ml}$ by micropipette \& put into $9 \mathrm{ml}$ of test-tube water respectively. Then from 1 st test-tube take $1 \mathrm{ml} \&$ put into 2 nd test-tube. It made $10 \mathrm{ml}$. Then from 2 nd test-tube taken $1 \mathrm{ml} \&$ put into $3 \mathrm{rd}$ test-tube. It made $10 \mathrm{ml}$. From the conical flask media was taken into petri dish in optimum amount. Then from 3rd dilution test-tube take small amount of sample steering upon the petridish. From the $3^{\text {rd }}$ test tube each sample taken 200 micro-liter \& put upon Petridis. Above those work done in laminerflow those Petridis put into incubator at $38^{\circ} \mathrm{C}$ for 24 hours.

Third Microbial Test of ginger (Fungal Test): After 16 Days for fungal test first media was prepared. For the $250 \mathrm{ml}$ of fungal media $10 \mathrm{gm}$ potato dextrose agar taken. Those were dissolved with $250 \mathrm{ml}$ of distill water. Those media were sterilized by automatic sterilizer at $121^{\circ} \mathrm{c} \& 20 \mathrm{~min}$. Every test tube taken $9 \mathrm{ml}$ distills water $\&$ packed with cotton. Media, Petridis, Test tube, Stirrer were sterilized by automatic sterilizer $121^{\circ}$ c \& $20 \mathrm{~min}$. Test for sample - 1,2 \& normal sample ; 5 times dilution : ginger sample- 1, 2 \& normal sample taken $1 \mathrm{ml}$ by micropipette \& put into $9 \mathrm{ml}$ of test-tube water respectively. Then from 1 st test-tube taken $1 \mathrm{ml} \&$ put into 2 nd test-tube. It made $10 \mathrm{ml}$. Then from 2 nd test-tube taken $1 \mathrm{ml} \&$ put into 3rd test-tube.

From the conical flask media was taken into Petridis in optimum amount. Then from 3rd dilution test-tube take small amount of sample steering upon the petri dish. From the $3^{\text {rd }}$ test tube each sample taken 200 micro-liter \& put upon Petridis. Above those work were done in laminerflow those Petridis are put into incubator at $38^{\circ} \mathrm{C}$ for 24 hours.

In this thesis work most important to produce pure chitosan powder. So preparation procedure and microbial test done carefully.

\section{Results}

Juice \& Ginger paste preserved at normal temperature\& observed every week. Those that gave obnoxious odor were discarded. Microbial count was taken for every week. Above table found that, day increase microbial growth also increase. In nil sample microbial count large amount after day to day. When chitosan Concentration. Increase microbial growth inhibit. In sample $1 \& 2$ microbial growth moderate but acceptable. Further application suggests that chitosan inhibit bacterial growth.

Table 1. Bacterial count in different juice stored at normal temperature

\begin{tabular}{|c|c|c|c|c|}
\hline \multirow{2}{*}{ Sample No } & \multirow{2}{*}{ Chitosan Concentration } & Storage Time & Storage Time & Storage Time \\
\hline & & After 3 days & After 8 days & After 16 days \\
\hline Sample Normal & Nil & $9.0-10^{4}$ & $1.5 \times 10-$ & $2.4 \times 10^{7}$ \\
\hline Sample - 1 & $0.5 \%$ & $5.5 \times 10^{4}$ & $6.5 \times 10^{\prime}$ & $9.5 \times 10^{6}$ \\
\hline Sample -2 & $1 \%$ & $3.3 \times 10^{4}$ & $5.0 \times 10^{5}$ & $6.5 \times 10^{6}$ \\
\hline
\end{tabular}

After $3,8 \& 16$ days bacterial count $9.0 \times 10^{4}, 1.5 \times 10^{5} \&$ $2.4 \times 10^{7}$ respectively. After $3,8 \& 16$ days bacterial count $5.5 \times 10^{4}, 6.5 \times 10^{5} \& 9.5 \times 10^{6}$ respectively for sample 1 . After 3,8 $\& 16$ days bacterial count $3.3 \times 10^{4}, 5.0 \times 10^{\prime \prime} \& 6.5 \times 10^{6}$ respectively for sample 2 . Above table- 1 we saw that normal sample contains higher level of bacterial colony. In sample $1 \& 2$ the bacterial colony is lower than the normal sample. For all the above samples bacterial colonies increases in direct proportion to the increase of days. The count of bacterial colony also decreases with the increasing rate of chitosan 
concentration.

Sample Normal after $3,8 \& 16$ days fungal count $4.3 \times 10^{5}$, $4.9 \times 10^{6} \& 6.5 \times 10^{7}$ respectively. After $3,8 \& 16$ days fungal count $2.6 \times 10^{5}, 2.0 \times 10^{6} \& 2.3 \times 10^{7}$ respectively for sample- 1 . After $3,8 \& 16$ days fungal count $4.5 \times 10^{4}, 3.5 \times 10^{5} \& 5.5 \times 10^{6}$ respectively for sample- 2 . Above table- 2 we saw that normal sample contains higher level of fungal colony. In sample $1 \& 2$ the fungal colony is lower than the normal sample. For all the above samples fungal colonies increases in direct proportion to the increase of days. The count of fungal colony also decreases with the increasing rate of chitosan concentration.

TabIe 2. Fungal count in different juice stored at normal temperature.

\begin{tabular}{|c|c|c|c|c|}
\hline \multirow{2}{*}{ Sample No } & \multirow{2}{*}{ Chitosan Concentration } & Storage Time & Storage Time & Storage Time \\
\hline & & After 3 days & After 8 days & After 16 days \\
\hline Sample Normal & Nil & $4.3 \times 10^{5}$ & $4.9 \times 10^{6}$ & $6.5 \times 10^{7}$ \\
\hline Sample -1 & $.5 \%$ & $2.6 \times 10^{5}$ & $2.0 \times 10^{6}$ & $2.3 \times 10^{7}$ \\
\hline Sample -2 & $1 \%$ & $45-10^{4}$ & $3.5 \times 10-$ & $5.5 \times 10^{6}$ \\
\hline
\end{tabular}

Table 3. Bacterial count in different ginger stored at normal temperature.

\begin{tabular}{|c|c|c|c|c|}
\hline \multirow{2}{*}{ Sample No } & \multirow{2}{*}{ Chitosan Concentration } & Storage Time & Storage Time & Storage Time \\
\hline & & After 3 days & After 8 days & After 16 days \\
\hline Sample Normal & Nil & $3.9 \times 10^{\prime}$ & $4.9 \times 10^{6}$ & $5.5 \times 10^{7}$ \\
\hline Sample -1 & $.5 \%$ & $1.1 \times 10^{5}$ & $1.4 \times 10^{6}$ & $2.4 \times 10^{7}$ \\
\hline Sample -2 & $1^{\circ} 0$ & $5.0 \times 10^{4}$ & $9.0 \times 10^{5}$ & $1.4 \times 10^{7}$ \\
\hline
\end{tabular}

Sample Normal after $3,8 \& 16$ days bacterial count $3.9 \times 10^{5}$, $4.9 \times 10^{6} \& 5.5 \times 10^{7}$ respectively. After $3,8 \& 16$ days bacterial count $1.1 \times 10^{5}, 1.4 \times 10^{6} \& 2.4 \times 10^{7}$ respectively for sample- 1 . After $3,8 \& 16$ days bacterial count $5 \times 10^{4}, 9.0 \times 10^{3} \& 1.4 \times 10^{7}$ respectively for sample- 2 . Above table- 3 we saw that normal sample contains higher level of bacterial colony. In sample
$1 \& 2$ the bacterial colony is lower than the normal sample. For all the above samples bacterial colonies increases in direct proportion to the increase of days. The count of bacterial colony also decreases with the increasing rate of chitosan concentration.

Table 4. Fungal count in different ginger stored at normal temperature.

\begin{tabular}{|c|c|c|c|c|}
\hline \multirow{2}{*}{ Sample No } & \multirow{2}{*}{ Chitosan Concentration. } & Storage Time & Storage Time & Storage Time \\
\hline & & After 3 days & After 8 days & After 16 days \\
\hline Sample Normal & Nil & $1.3 \times 10^{5}$ & $1.9 \times 10^{6}$ & $2.7 \times 10^{7}$ \\
\hline Sample -1 & $0.5 \%$ & $4.5 \times 10^{4}$ & $7.5 \times 10^{5}$ & $1.3 \times 10^{7}$ \\
\hline Sample -2 & $1 \%$ & $3.5 \times 10^{4}$ & $6.5 \times 10^{\prime}$ & $1 \times 10^{7}$ \\
\hline
\end{tabular}

Sample Normal after $3,8 \& 16$ days fungal count $1.3 \times 10^{5}$ $1.9 \times 10^{6} \& 2.7 \times 10^{7}$ respectively. After $3,8 \& 16$ days fungal count $4.5 \times 10^{4}, 7.5 \times 10^{5} \& 1.3 \times 10^{7}$ respectively for sample- 1 . After 3,8 \& 16 days fungal count $3.5 \times 10^{4}, 6.5 \times 10^{5} \& 1 \times 10^{1}$ (respectively for sample- 2 . Above table- 4 we saw that normal sample contains higher level of fungal colony. In sample $1 \& 2$ the fungal colony is lower than the normal sample. For all the above samples fungal colonies increases in direct proportion to the increase of days. The count of fungal colony also decreases with the increasing rate of chitosan concentration.

\section{Discussion}

The chemical structure of chitin [poly- $\beta-(1 \rightarrow 4)-\mathrm{N}$-acetyl$\mathrm{D}$-glucosamine] is similar to cellulose, with this difference that in chitosan one hydroxyl group on each monomer has substituted with an acetylamine group. Chitosan is a modified, natural carbohydrate polymer derived by deacetylation of chitin with the average molecular weight 1.0 to $5 \times 105 \mathrm{Da}^{[15]}$. Zahed Hossain et al. reported ${ }^{[16]}$ the preparation of chitin from shrimp shells and the common procedure for isolating chitin from shrimp shell involves demineralization, deproteinization and decoloration. Industrially, chitosan are normally prepared by alkaline de-N-acetylation of chitin $^{[17]}$. The typical production of chitosan from crustacean shell generally consists of four basic steps: demineralization, deproteinization, decoloration and deacetylation ${ }^{[18]}$.

\section{Conclusion}

Use of chitosan as preservative in orange juice and ginger is an alternative to the other chemical preservative. Shrimp shell in Bangladesh is good source of chitosan preparation is easiest from processing waste 11 has some beneficial roles against heart disease, kidney disease and liver disease. Most important role in preservation various food product in this context this research work could play a significant role in preservative and the protection of various complex disease. So we can say chitosan is a good preservative.

The researcher found in his research work that chitosan act against bacteria and fungi. Chitosan of sample- 2 was proved to be more active preservative than chitosan of sample-1. Chitosan increase the shelf life of orange juice and ginger paste for 8 days. The researcher also found a relation between the chitosan concentration and shelf life of raw food. It was proved in his work that shelf life of raw food which contains chitoisan increases with the increasing concentration of chitosan. 
Preservative use of chitosan in orange juice and ginger are important. Shrimp shell in Bangladesh is good source of chitosan. So here chitosan preparation is easy. Most important role in preservation various food product in this context this research work could play a significant role in preservative and the protection of various complex disease. So we can say chitosan is a good preservative.

\section{References}

[1] Shahidi, F.; Abuzaytoun, R., Adv. Food Nutr. Res., 2005, 49, 93- 135 .

[2] Tharanathan, R.N.; Kittur, F.S., Crit. Rev. Food. Sci. Nutr., 2003, 43, 61-87.

[3] S. Arcidiacono, and D. L. Kaplan, "Molecular weight distribution of chitosan isolated from Mucor rouxii under different culture and processing conditions," Biotechnology and Bioengineering, vol. 39, pp. 281-286, 1992.

[4] Aider M (2010) Chitosan application for active bio-based films production and potential in the food industry: Review. Food Sci Technol-LEB 43: 837-842.

[5] P. C. Srinivasa, and R. N. Tharanathan, "Chitin/Chitosan Safe, Ecofriendly Packaging Materials with Multiple Potential Uses," Food Reviews International, vol. 23, no. 1, pp. 53-72, 2007.

[6] Santos NSD, Aguiar AJA, Oliveira CED, Sales CVD, Silva SDM, et al. (2012) Efficacy of the application of a coating composed of chitosan and Origanum vulgare L. essential oil to control Rhizopus stolonifer and Aspergillus niger in grapes (Vitis labrusca L.). Food Microbiol 32: 345-353.

[7] Perdones A, Sánchez-González L, Chiralt A, Vargas M (2012) Effect of chitosan-lemon essential oil coatings on storage-keeping quality of strawberry. Postharvest Biol Tec 70: $32-41$.
[8] Yu YW, Zhang SY, Ren YZ, Li H, Zhang XN, et al. (2012) Jujube preservation using chitosan film with nano-silicon dioxide. J Food Eng 113: 408-414.

[9] Xing Y, Li X, Xu Q, Jiang YH, Yun J, et al. (2010) Effects of chitosan-based coating and modified atmosphere packaging (MAP) on browning and shelf life of fresh-cut lotus root (Nelumbo nucifera Gaerth). Innov Food Sci Emerg 11: 684-689.

[10] N. Liu, X. G. Chen, H. J. Park, C. G. Liu, C. S. Liu, X. H. Meng, and L. J. Yu, "Effect of MW and concentration of chitosan on antibacterial activity of Escherichia coli," Carbohydrate Polymers, vol. 64, pp. 60-65, 2006.

[11] H. K. No, N. Y. Park, S. H. Lee, H. J. Hwang, and S. P. Meyers, "Antibacterial activities of chitosans and chitosan oligomers with different molecular weights on spoilage bacteria isolated from tofu," Journal of Food Science, vol. 67, no. 4, pp.1511-1514, 2002.

[12] H. Sashiwa and S. Aiba, "Chemically modified chitin and chitosan as biomaterials," Progress in Polymer Science, vol. 29, pp. 887-908, 2004.

[13] Pradip Kumar Dutta, Joydeep Dutta and V S Tripathi, J. Sc. Ind. Res., 2004, 63, 20-31.

[14] [Kumar M. N. V. R., React. Funct. Polym., 2000, 46(1), 1-27.

[15] M. N. V. Ravikumar, "A review of chitin and chitosan application. Reactive Functional Polymer, vol. 46, pp. 1-27, 2000 .

[16] Zahed Hossain, Asaduzzaman, M.A. Kashem, Bazlul Karim Akanda, S.K. Roy and Shahidul Islam, Bangladesh J. Sc. Ind. Res.2005, 40(3-4), 163-168.

[17] Hirano, S., Biotechnology Annu. Rev., 1996, 2,235-238.

[18] No, H. K., \& Lee, M. Y., J Korean Soc Food Nutr, 1995, 24, 105-113. 